\title{
Analisis Potensi Desa Wisata di Kertajaya, Kecamatan Ciranjang, Kabupaten Cianjur, Provinsi Jawa Barat
}

\author{
Hanny Hanny1, Lidya Agustina*2, Debbianita ${ }^{3}$, Endah Purnama Sari4, Elysabeth I Marpaung5, Maria \\ Natalia $^{6}$, Verani Carolina7 ${ }^{7}$ Joni Joni ${ }^{8}$, Daniel Togu Halomoan ${ }^{9}$, Leliana ${ }^{10}$ \\ 1,2,3,4,5,6,7,8,9,10Program Studi Akuntansi, Fakultas Bisnis, Universitas Kristen Maranatha \\ *e-mail: hanny@eco.maranatha.edu1, lidya.agustina@eco.maranatha.edu², debbianita@eco.maranatha.edu \\ 3, endah.pe@eco.maranatha.edu ${ }^{4}$, elyzabet.im@eco.maranatha.edu ${ }^{5}$, maria.natalia@eco.maranatha.edu 6 , \\ verani.carolina@eco.maranatha.edu ${ }^{7}$,joni@eco.maranatha.edu ${ }^{8}, 2051018 @ e c o . m a r a n a t h a . e d u{ }^{9}$, \\ 2057030@eco.maranatha.edu10
}

\begin{abstract}
Indonesia has enormous potential tourism to be developed because it has a diversity of natural resources and culture. The development of local tourism needs to be continued to improve local communities' welfare. However, there are a lot of local tourism potentials in villages which have not been explored and exposed. Through community services, academics world could be connected with the village to explore the villages' potentials and to develop them into tourist villages. This study aims to explore the potential tourism of Kertajaya village based on various aspects and constraints, then to analyze the tourism potentials of Kertajaya Village which could be developed more. The method we used in this research is descriptive with qualitative analysis. Based on the results of some interviews and surveys that we conducted in Kertajaya Village, it can be concluded that Kertajaya Village is potential to become a Tourism Village because of their natural resources, culture, and society.
\end{abstract}

Keywords: Potential tourism; Tourist village; Kertajaya Village

\begin{abstract}
Abstrak
Indonesia memiliki potensi wisata yang sangat besar untuk dikembangkan karena memiliki keanekaragaman kekayaan alam dan budaya. Pengembangan potensi wisata local perlu terus dilakukan agar meningkatkan kesejahteraan masyarakat lokal. Namun masih banyak potensi wisata local, khususnya yang terdapat di desa-desa yang belum tergali dan terekspose. Melalui pengabdian masyarakat, dunia akademik akan dapat terhubung dengan desa untuk mengeksplorasi potensi desa dan mengembangkannya menjadi desa wisata. Penelitian ini bertujuan untuk menggali potensi pariwisata desa Kertajaya dengan melihat dari berbagai aspek dan kendala, serta menganalisis potensi pariwisata Desa Kertajaya yang mungkin dapat dikembangkan lebih lanjut. Metode yang digunakan dalam penelitian ini bersifat deskriptif, dengan analisis kualitatif. Berdasarkan hasil wawancara dan survey yang kami lakukan di Desa Kertajaya, dapat disimpulkan bahwa Desa Kertajaya cukup berpotensi menjadi Desa Wisata karena kekayaan alam, budaya dan kondisi masyarakatnya.
\end{abstract}

Kata kunci: Potensi wisata; Desa wisata; Desa Kertajaya

\section{PENDAHULUAN}

Indonesia merupakan negara yang memiliki potensi wisata yang sangat besar untuk dikembangkan, karena Indonesia memiliki daya tarik wisata berupa lebih dari 17000 pulau 300 suku bangsa, 742 bahasa, 51 taman nasional, dan keanekaragaman hayati terbesar ketiga di dunia. Daya Tarik Wisata adalah segala sesuatu yang memiliki keunikan, keindahan, dan nilai yang berupa keanekaragaman kekayaan alam, budaya, dan hasil buatan manusia yang menjadi sasaran atau tujuan kunjungan wisatawan (UU RI No. 10 Tahun 2009 tentang Kepariwisataan). Indonesia memiliki visi menjadi salah satu destinasi wisata utama di Asia dan di dunia pada tahun 2045, oleh karena itu Pemerintah menargetkan total kunjungan wisatawan mancanegara sebanyak 30 juta orang di tahun 2024, kemudian meningkatkan devisa sektor pariwisata menjadi 40 juta USD dan menjadi peringkat 30 di tahun 2024 dalam peringkat daya saing wisata dan perjalanan (Lembaga Penyelidikan Ekonomi dan Masyarakat Fakultas Ekonomi dan Bisnis Universitas Indonesia, 2018).

Sektor kepariwisataan perlu dikembangkan agar mendorong kegiatan ekonomi dan meningkatkan citra Indonesia, meningkatkan kesejahteraan masyarakat lokal, serta memberikan perluasan kesempatan kerja (Lembaga Penyelidikan Ekonomi dan Masyarakat Fakultas Ekonomi 
dan Bisnis Universitas Indonesia, 2018). Pariwisata merupakan salah satu sektor penggerak perekonomian yang perlu diberi perhatian lebih agar dapat berkembang dengan baik (Zakaria \& Suprihardjo, 2014). Pariwisata adalah alternatif ramah lingkungan dan terbarukan yang mampu meningkatkan perekonomian masyarakat, pelestarian sumber daya alam, dan pengenalan budaya (Crnogaj et al., 2014; Sutawa, 2012). Dengan demikian, maka pariwisata menjadi salah satu aspek dalam peningkatan ekonomi di Indonesia. Adanya sektor pariwisata akan menimbulkan manfaat masyarakat setempat dan berpotensi positif bagi masyarakat penyedia jasa dalam mendatangkan wisatawan (Andriani et al., 2020).

Zakaria (2017) menjelaskan bahwa pembentukan Badan Usaha Milik Desa (BUMDes), diyakini bisa membawa tatanan ekonomi di wilayah pedesaan menjadi lebih baik. BUMDes adalah badan hukum yang didirikan oleh desa dan/atau bersama desa-desa guna mengelola usaha, memanfaatkan asset, mengembangkan investasi dan produktivitas, menyediakan jasa pelayanan, dan/atau menyediakan jenis usaha lainnya untuk sebesar-besarnya kesejahteraan masyarakat Desa (Peraturan Pemerintah Republik Indonesia Nomor 11 Tahun 2021 Tentang Badan Usaha Milik Desa, 2021). Menurut Shohibuddin (2016) dalam Adam et al. (2020), desa perlu diberikan kesempatan dan keleluasaan untuk membangun dan mengembangkan wilayahnya agar dapat mencapai kesejahteraannya, dan dapat setara dengan daerah perkotaan. Dengan demikian, maka potensi desa perlu terus dicari dan digali, serta dikembangkan agar masyarakat desa dapat mencapai kesejahteraanya.

Program Studi Akuntansi Fakultas Bisnis Universitas Kristen Maranatha bekerjasama dengan Desa Kertajaya, khususnya melalui BUMDes Kertajaya berupaya menggali potensi yang dimiliki oleh Desa Kertajaya sebagai potensi wisata. Desa Kertajaya memiliki beberapa tempat yang mempunyai potensi untuk dijadikan tempat wisata, salah satu wisata yang akan dikembangkan berada di wilayah Kampung Palalangon RW 09 dan juga Kampung Babakan Garut RW 05. Saat ini sudah terdapat beberapa wisata yang ada di desa Kertajaya khususnya di dekat danau Cirata yang merupakan tempat umggulan di desa tersebut, yaitu wisata pemancingan dan wisata bioflok. Pengelola BUMDes berharap dengan adanya pengelolaan dan penataan yang baik bukan hanya pemancing yang akan datang, namun para wisatawan lainnya juga dapat menikmati keindahan alam di wisata desa Kertajaya (Kurniawan, 2021).

Namun demikian, menurut pengelola BUMDes Kertajaya masih banyak kemungkinan potensi wisata yang dapat digali dari Desa Kertajaya, sehingga BUMDes Kertajaya bekerjasama dengan Program Studi Akuntansi Fakultas Bisnis Universitas Kristen Maranatha mencoba menggali potensi pariwisata desa Kertajaya dengan melihat dari berbagai aspek, kendala, serta berbagai potensi yang dimiliki Desa Kertajaya yang mungkin dapat dikembangkan sebagai potensi wisata.

\section{METODE}

\subsection{Objek Penelitian}

Desa Kertajaya, Kecamatan Ciranjang, Kabupaten Cianjur, Provinsi Jawa Barat merupakan objek dalam penelitian ini, sedangkan pengurus BUMDes Kertajaya dan pengelola unit wisata di desa Kertajaya adalah subjek dalam penelitian ini.

\subsection{Metode Penelitian}

Penelitian ini bersifat deskriptif, yaitu menggambarkan suatu keadaan desa, masyarakat dan pemerintah di Desa Kertajaya dalam kaitannya mengelola potensi wisata melalui BUMDes. Analisis data yang digunakan dalam penelitian ini adalah analisis data kualitatif, seluruh data yang terkumpul akan dianalisis, dihubungkan antara satu dengan yang lain dan disajikan secara deskriptif dan sistematis. 


\subsection{Teknik Pengumpulan Data}

Data yang digunakan dalam penelitian ini berupa data primer dan data sekunder. Data primer yaitu penelitian yang dilakukan di lapangan dengan mengumpulkan jawaban dari responden, dan data sekunder terdiri dari peraturan perundang-undangan, peraturan menteri, peraturan desa, buku-buku, jurnal-jurnal dan literatur lain yang terkait dengan pembahasan pengelolaan pariwisata dan BUMDes, kamus serta situs internet.

Teknik pengumpulan data yang digunakan dalam penelitian ini adalah teknik studi dokumen dan teknik wawancara. Studi dokumen dilakukan pada tahap awal untuk mencari literatur tentang pembahasan pariwisata, pengelolaan wisata dan BUMDes. Teknik wawancara bertujuan memperoleh jawaban-jawaban yang relevan dengan masalah penelitian yang bersumber dari informan. Informan untuk penelitian ini adalah Pengelola BUMDes dan pengurus unit wisata.

Wawancara dilakukan untuk menggali potensi desa wisata yang ada di Kertajaya, pertanyaan-pertanyaan wawancara meliputi dimensi sikap dan tata kehidupan masyarakat; aksesibilitas; amenity; kelembagaan, promosi dan informasi, serta budaya dan situs purbakala. Untuk beberapa pertanyaan dalam wawancara digunakan indikator pengukuran untuk masingmasing dimensi sebagai berikut:

Tabel 1. Indikator penilaian dimensi penelitian

\begin{tabular}{lll}
\hline \multicolumn{1}{c}{ Elemen } & \multicolumn{1}{c}{ Total Skor } & \multicolumn{1}{c}{ Keterangan Penilaian } \\
\hline Sikap dan Tata & $1-1.25$ & Sangat tidak terbuka \\
Kehidupan & $1.26-2.25$ & Kurang terbuka \\
Masyarakat & $2.26-3.25$ & Cukup terbuka \\
& $3.26-4$ & Sangat terbuka \\
& $1-1.25$ & Sangat sulit dicapai \\
Aksesibilitas & $1.26-2.25$ & Sulit dicapai \\
& $2.26-3.25$ & Mudah dicapai \\
& $3.26-4$ & Sangat mudah dicapai \\
& $1-1.25$ & Sangat tidak terpenuhi \\
Amenity & $1.26-2.25$ & Kurang terpenuhi \\
& $2.26-3.25$ & Terpenuhi \\
Kelembagaan & $3.26-4$ & Sangat terpenuhi \\
Promosi, \& & $1-1.25$ & Sangat tidak mendukung \\
Informasi & $1.26-2.25$ & Kurang mendukung \\
& $2.26-3.25$ & Cukup mendukung \\
\hline
\end{tabular}

\subsection{Teknik Analisis Data}

Data yang diperoleh dari hasil wawancara selanjutnya akan direkap dan dinilai berdasarkan table 1 indikator penilaian dimensi penelitian untuk dilhat kecukupan point pencapaian sebagai desa wisata.

\section{HASIL DAN PEMBAHASAN}

3.1 Gambaran Pengelolaan Badan Usaha Milik Desa (BUMDes) Di Desa Kertajaya, Kecamatan Ciranjang, Kabupaten Cianjur, Provinsi Jawa Barat

Desa Kertajaya adalah sebuah desa seluas 384,44 hektar yang memiliki sekitar 8.916 penduduk (data tahun 2017) dan terletak di Kecamatan Ciranjang, Kabupaten Cianjur, Provinsi Jawa Barat (Hanny et al., 2020). Mereka memiliki Badan Usaha Milik Desa (BUMDes) sejak tahun 2014 (Hanny et al., 2020). Saat ini BUMDes Kertajaya Sawarga dikepalai oleh seorang direktur 
bernama Atep Kurniawan. Agenda utama BUMDes Kertajaya ini adalah meningkatkan Pendapatan Asli Daerah (PAD) untuk meningkatkan kesejahteraan masyarakat sekitar melalui pengembangan industri wisata khususnya di wilayah Babakan Garut dan Kampung Palalangon (Kurniawan, 2021). Sejalan dengan pemikiran perangkat kepengurusan BUMDes Kertajaya, hasil analisis pemetaan profil BUMDes Kertajaya Sawarga menunjukkan bahwa salah satu potensi yang dimiliki oleh Desa Kertajaya adalah di bidang pariwisata (Hanny et al., 2020).

Dalam kegiatan pengabdian pada masyarakat ini, tim kami mencoba melakukan analisis lebih mendalam dan spesifik mengenai jenis potensi pariwisata Desa Kertajaya yang dapat dikembangkan sekaligus yang menjadi prioritas dalam pengembangannya. Analisis potensi Desa Kertajaya di bidang pariwisata ini dilakukan dari dimensi: (A) sikap dan tata kehidupan masyarakat, (B) aksesibilitas, (C) amenity, (D) kelembagaan, promosi dan informasi, serta (E) budaya dan situs purbakala yang dikembangkan dari penelitian (Gunn \& Var, 2002; Jati et al., 2014; Sjamsu \& Dahrma, 2018; Spillane, 1997; Tyas \& Damayanti, 2018) Hasil analisis potensi Desa Kertajaya ini akan dibahas pada bagian selanjutnya.

3.2 Analisis Potensi Desa Kertajaya, Kecamatan Ciranjang, Kabupaten Cianjur, Provinsi Jawa Barat di Bidang Pariwisata

Berdasarkan wawancara dengan perangkat kepengurusan BUMDes Kertajaya Sawarga yang dilaksanakan pada tanggal 15 April 2021 dan berdasarkan hasil visitasi/kunjungan ke BUMDes Kertajaya pada tanggal 21 April 2021, maka hasil analisa potensi Desa Kertajaya di bidang pariwisata adalah sebagai berikut:

\section{A. Sikap dan Tata Kehidupan Masyarakat}

Mata pencaharian mayoritas penduduk Desa Kertajaya adalah petani, pedagang, dan nelayan. Kegemaran masyarakat Desa Kertajaya dalam menghabiskan waktu luangnya adalah melakukan kegiatan memancing dan berolahraga. Namun Ibu-ibu rumah tangga Desa Kertajaya memiliki kegemaran menonton TV di saat waktu luangnya.

Indeks sikap dan tata kehidupan masyarakat Desa Kertajaya dimana BUMDes Kertajaya berada adalah 3,33. Indeks ini menunjukkan bahwa masyarakat Desa Kertajaya memiliki sikap sangat terbuka. Pada dasarnya, penduduk Desa Kertajaya sangat ramah terhadap wisatawan (pendatang) dan sangat mudah tergerak hatinya untuk membantu wisatawan (pendatang) yang membutuhkan pertolongan. Dari sisi potensi konflik, penduduk Desa Kertajaya memiliki potensi konflik yang tidak terlalu tinggi. Jika terjadi konflik, mereka masih dapat menerima masukan dan pengertian yang diberikan oleh orang lain.

Saat ini, penduduk Desa Kertajaya mendukung agenda BUMDes untuk mengembangkan desa mereka menjadi Desa Wisata sejak tahun 2021. Untuk itu mereka menyambut baik kedatangan para wisatawan/pendatang ke desa mereka. Sebagai informasi bahwa saat ini terdapat benih-benih usaha di bidang pariwisata yang didukung masyarakat di bawah pengelolaan BUMDes Kertajaya, seperti:

1. Wisata Air dan Pemancingan $\rightarrow$ diorganisir oleh Pak Atep,

2. Wisata Seni dan Budaya $\rightarrow$ diorganisir oleh Pak Fadil Darmawan,

3. Wisata Bumi Perkemahan $\rightarrow$ diorganisir oleh Pak Nandang,

4. Wisata Live In dan Kerukunan Umat Beragama $\rightarrow$ diorganisir oleh Pak Yoenarta,

5. Wisata Kuliner $\rightarrow$ diorganisir oleh Pak Cucu Santana

6. Wisata Religi dan Hutan Lindung $\rightarrow$ diorganisir oleh Pak Albertinus

7. Wisata BioVlog $\rightarrow$ diorganisir oleh Pak Mahfud 
Walaupun benih-benih usaha pariwisata tersebut belum terorganisir secara memadai dan belum berkembang secara optimum, namun masyarakat penduduk Desa Kertajaya sudah mulai merasakan manfaat dari keberadaan benih-benih usaha pariwisata ini. Sebelum pandemi Covid19 di awal tahun 2020, desa mereka pernah menerima kedatangan beberapa wisatawan. Hal ini membuat mereka mulai terbiasa dan tidak sungkan untuk menghadapi kedatangan wisatawan/pendatang dari luar Desa Kertajaya. Berdasarkan kondisi ini, maka dari dimensi sikap dan tata kehidupan masyarakat, Desa Kertajaya memiliki potensi yang sangat memadai untuk menjadi sebuah Desa Wisata.

\section{B. Aksesibilitas}

Dari dimensi aksesibilitas, Desa Kertajaya masih termasuk ke dalam kategori Desa Wisata yang sulit dicapai. Hal ini ditunjukkan dari indeks Aksesibilitas sebesar 2. Sebenarnya, untuk menuju lokasi wisata Desa Kertajaya, terdapat dua jalan yang dapat ditempuh, yakni:

\section{Jalan Kesatu:}

Kondisi jalan alternatif kesatu ini cukup baik (telah dibeton), namun ukuran jalannya cukup sempit dan hanya dapat dilalui oleh 1 mobil (dengan asumsi: bukan mobil besar sejenis bis). Di samping itu, jarak tempuhnya lebih jauh (sekitar $5 \mathrm{~km}$ dari jalan utama Kecamatan Ciranjang)

2. Jalan Kedua:

Jalan alternatif kedua ini memiliki ukuran yang cukup lebar sehingga dapat dilalui oleh dua mobil secara berdampingan/dua arah (dengan asumsi: bukan mobil besar sejenis bis). Jarak tempuhnyapun lebih dekat (sekitar 3,5 km dari jalan utama Kecamatan Ciranjang). Namun kondisi jalan alternatif kedua ini kurang baik dan berlubang, walaupun masih memungkinkan untuk dilewati.

Pada umumnya, masyarakat Desa Kertajaya menggunakan motor dan mobil pribadi sebagai alat transportasi pribadi. Satu-satunya alat transportasi umum adalah ojek (motor) di lokasi tertentu. Berdasarkan dari kondisi tersebut, untuk mendukung pengembangan Desa Wisata secara optimum maka dimensi aksesibilitas ini masih perlu ditingkatkan terutama melalui pembangunan infrastruktur berupa jalan yang lebar dan dalam kondisi baik serta fasilitas transportasi yang memiliki daya tampung lebih banyak serta dan variatif untuk mendampingi fasilitas ojek yang telah ada saat ini. Harapannya adalah terciptanya aksesibilitas ke lokasi wisata Desa Kertajaya yang memberikan kemudahan, kenyamanan dan pengalaman indah bagi perjalanan para wisatawan yang hendak berkunjung dan menikmati wisatanya di Desa Wisata Kertajaya. Tentu hal ini akan meningkatkan daya tarik bagi para calon wisatawan sehingga mampu mendukung daya saing Desa Wisata Kertajaya.

\section{Amenity}

Desa Kertajaya memiliki indeks dari dimensi amenity sebesar 3,17. Hal ini berarti fasilitas pendukung kelancaran kegiatan pariwisata di Desa Kertajaya cukup memenuhi harapan wisatawan untuk menikmati kegiatan wisatanya secara nyaman dan lancar. Di daerah wisata Desa Kertajaya belum terdapat fasilitas guesthouse maupun hotel, namun masyarakat bersedia menampung wisatawan untuk menginap secara dadakan. Daya tampung perumahan warga bagi wisatawan adalah sebanyak 10 orang. BUMDes Kertajaya bekerjasama dengan masyarakat sekitar mengupayakan fasilitas akomodasi yang cukup menampung 100 orang wisatawan dengan cara mendayagunakan lokasi pemancingan dan menyediakan akomodasi dalam bentuk perkemahan. Fasilitas akomodasi tersebut masih perlu dikembangkan untuk mendukung keberhasilan pembangunan Desa Wisata di Desa Kertajaya.

Dari sisi konsumsi, daerah wisata Desa Kertajaya telah tersedia banyak pilihan rumah makan yang cukup terawat dengan baik walaupun sederhana. Prinsip yang dikembangkan oleh rumah makan sekitar daerah wisata adalah "sederhana, mengenyangkan dan terjangkau" bagi 
wisatawan. Sebagai contoh: bagi menu yang menyajikan daging sebagai salah satu lauk pauknya dapat dijual cukup dengan harga Rp.15.000,-/porsi pada tahun 2021. Namun demikian konsumen akan merasa kenyang dengan ukuran porsi yang disajikan dan penyajiannya cukup higienis. Sajian kuliner umum yang disediakan di Desa Kertajaya adalah ikan bakar (berikut nasi, lalapan dan sambal khas Kertajaya). Kuliner yang diunggulkan adalah nasi timbel/liwet Papadil yang diramu dengan rempah-rempah tradisional. Desa Wisata di Desa Kertajaya juga memiliki beberapa makanan tradisional lain yang cukup berpotensi untuk menarik minat wisatawan datang dan mencicipinya, yakni:

1. Goreng Pepetek $\rightarrow$ kuliner yang berbahan dasar baby fish (ikan kecil) dan diberikan bumbu khas, kemudian digoreng sebelum disajikan.

2. Pungpa $\rightarrow$ camilan (snack) berbahan dasar tepung kelapa yang diberikan bumbu khusus dan digoreng sehingga memberikan rasa gurih saat dicicipi. Camilan ini disajikan dalam kemasan yang cukup higienis, menarik dan modern dengan dua rasa pilihan yaitu: original dan pedas. Kenikmatan rasa camilan khas Desa Kertajaya ini membuat camilan ini cocok untuk dijadikan oleh-oleh maupun sajian untuk berbuka puasa seperti yang telah mereka lakukan saat bulan Ramadhan.

Keberadaan kuliner Goreng Pepetek dan Pungpa ini dapat menjadi Social Attraction bagi Desa Wisata di Kertajaya. Hal ini tentu dapat menjadi keunggulan bagi Desa Wisata tersebut. Nilai lebih yang diberikan oleh Desa Wisata Kertajaya adalah tersedia fasilitas tempat parkir yang luas disertai dengan layanan yang baik. Lahan parkir ini telah dibeton sehingga nyaman untuk dijadikan tempat parkir kendaraan para wisatawan. Kapasitas lahan parkir tersebut adalah 200 mobil. Pengelolaan lahan parkir ini dilakukan oleh BUMDes Kertajaya bekerjasama dengan Dinas Perhubungan dan pihak asuransi.

Desa Wisata Kertajaya menyediakan fasilitas perbelanjaan oleh-oleh dengan variasi produk yang cukup banyak mencakup produk khas daerah mereka maupun produk umum. Mereka memiliki 5 produk khas dan unggulan, yakni: Pungpa (Gambar 2.1), Keripik Pisang (Gambar 2.1), Beras Cianjur, Ikan Asin Gabus dan Pepetek. Untuk memenuhi kebutuhan seharihari, wisatawan dapat membelinya di toko kelontong. Sebagai informasi bahwa fasilitas belanja kebutuhan sehari-hari dalam bentuk minimart belum tersedia di Desa Wisata Kertajaya, namun mereka menyediakan pula sistem penjualan dengan menggunakan kano sehingga wisatawan dapat memenuhi kebutuhan hariannya dengan cara unik bak berbelanja ala floating market.

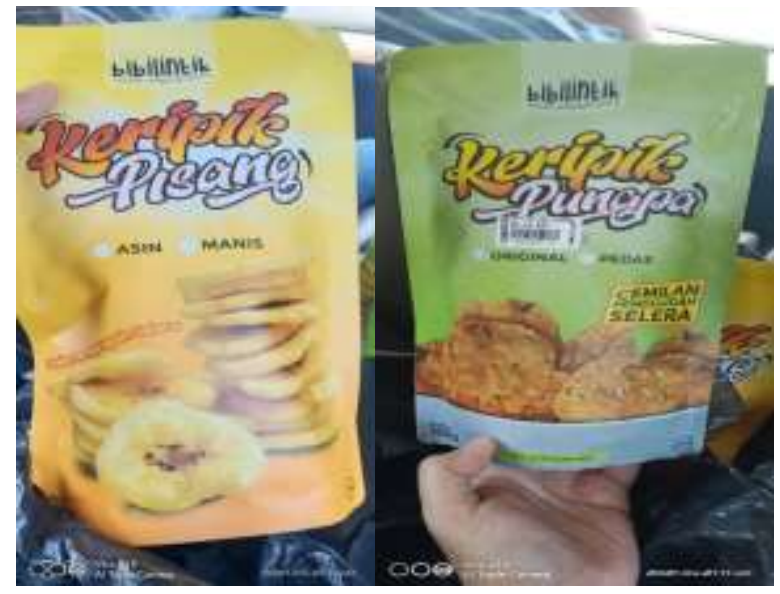

Gambar 1. Produk Keripik Pisang dan Keripik Pungpa Desa Kertajaya

Berdasarkan kondisi tersebut, tentu tak heran jika analisis potensi desa wisata Desa Kertajaya dari sisi Amenity dianggap cukup memenuhi standar. Namun demikian, ada beberapa hal yang tetap perlu dikembangkan untuk membuat wisatawan merasa bahwa harapannya sangat 
terpenuhi di Desa Wisata Kertajaya dari sisi Amenity, seperti: pembangunan guesthouse, pengembangan fasilitas perkemahan yang lebih menarik dan modern, pembangunan penerangan (dimana penerangan sudah ada di Desa Wisata Kertajaya dan cukup terang di area dermaga, namun cukup redup di sepanjang jalan menuju area Desa Wisata).

\section{Kelembagaan, Promosi dan Informasi}

BUMDes Kertajaya telah mengembangkan kegiatan promosi Desa Wisatanya. Mereka memiliki media promosi cetak (brosur/pamphlet) di suatu lokasi atau acara/kegiatan tertentu (seperti: lomba memancing di alam) serta memiliki media promosi berbasis digital melalui media sosial. Mereka memiliki akun di Facebook yang beranggotakan penggemar kegiatan mancing dan menjadikannya sebagai komunitas pemancing. Anggota komunitas tersebut berjumlah 1000 orang dan diberi nama Balebat (Babakan Garut Lestari dan Bermartabat). Melalui komunitas mereka di media sosial Facebook, setiap anggota komunitas dapat memiliki kesempatan untuk mempromosikan tempat berteduh/lapak dan rakit yang hendak disewakan. Dari masyarakat dan untuk masyarakat, itulah gambaran dari kegiatan tersebut. Saat ini, BUMDes cukup mendukung komunitas ini dan menjadikannya sebagai bagian dari kegiatan BUMDes. Beberapa kegiatannya bahkan telah disajikan di Youtube.

Dari sisi fasilitas internet di Desa Kertajaya khususnya di babakan Garut (salah satu lokasi wisata Desa Kertajaya), jumlah penduduk yang memiliki fasilitas internet ini masih di bawah 10\%. Namun sinyal internet cukup stabil dan memadai di Desa Wisata tersebut.

Dari sisi kelembagaan, Desa Wisata di Desa Kertajaya ini telah memiliki organisasi pengelola wisata namun mereka hanya aktif melayani para wisatawan di waktu tertentu. Saat ini, BUMDes sedang berusaha untuk menyusun standar pelayanan tertentu.

Berdasarkan kondisi di atas, maka tak heran jika indeks potensi Desa Wisata di Kertajaya mencapai 2,67. Ini berarti bahwa hal-hal yang berkaitan dengan kelembagaan/pengelola, promosi dan informasi mengenai Desa Wisata di Desa Kertajaya cukup mendukung pengembangan Desa Wisatanya.

\section{E. Budaya dan Situs Purbakala}

Desa Kertajaya kaya akan budaya. Mereka memiliki beberapa budaya yang menarik, seperti: Pecak Silat, Tarian Jaipongan, Calung, dan Reog. Melalui keberadaan budaya ini, Desa Wisata di Kertajaya dapat menghasilkan berbagai cendera mata, seperti miniatur Calung, dll) sehingga berpotensi untuk menambah daftar oleh-oleh yang dapat dibeli oleh para wisatawan. Dengan keberadaan budaya ini pula, Desa Kertajaya berpotensi pula untuk mengembangkan Desa Wisata yang memiliki cultural attraction, dimana wisatawan dapat turut serta tampil dalam acara yang berkaitan dengan budaya di Kertajaya.

Selain memiliki budaya khas yang dapat menarik pihak wisatawan, Desa Kertajaya memiliki beberapa situs purbakala berupa gua, dll yang belum diolah sebagai lokasi wisata. Mereka juga memiliki hutan lindung yang cukup luas di daerah Cirata dan dapat dijadikan sebagai lokasi perkemahan yang menarik. Hal ini menjadi natural attraction bagi para wisatawan Desa Wisata di Kertajaya.

\subsection{Pembahasan tentang Potensi Desa Kertajaya di Bidang Pariwisata Berdasarkan Hasil Analisisnya}

Berdasarkan hasil analisis yang tersaji di bagian 4.2 di atas, maka secara keseluruhan rerata indeks potensi Desa Wisata di Desa Kertajaya $=(3,33+2+3,17+2,67): 4=2,79$. Hal ini berarti Desa Kertajaya cukup berpotensi untuk menjadi Desa Wisata yang menarik bagi wisatawan. Pengembangan Desa Wisata di Desa Kertajaya cukup layak dan menarik untuk dilakukan. 
Namun demikian terdapat beberapa hal yang perlu diperbaiki atau ditingkatkan sehubungan dengan pengembangan Desa Wisata ini, yakni:

a. Fasilitas jalan menuju lokasi yang lebar, baik dan cukup penerangannya.

b. Fasilitas akomodasi berupa guesthouse

c. Pemberdayaan masyarakat dalam menciptakan industri kreatif dan industri budaya

d. Fasilitas transportasi umum yang memiliki daya tampung lebih besar, seperti: Angkutan Kota.

e. Konsistensi layanan dan jam layanan bagi wisatawan

Secara umum, 7 (tujuh) benih usaha bidang pariwisata di Desa Kertajaya merupakan langkah awal yang baik dalam pembangunan dan pengembangan Desa Wisata Kertajaya. Ketujuh benih usaha ini cukup berpotensi mengundang minat wisatawan/pendatang untuk mengunjungi lokasi wisata. Terbukti jumlah pengunjungnya sebelum pandemi dapat mencapai angka 1.0001.500 pengunjung setiap minggu. Namun demikian, pendampingan dalam pengelolaan Desa Wisata ini perlu dilakukan. Dengan keberadaan lebih dari satu benih usaha bidang pariwisata di Desa Kertajaya saat ini, maka akan lebih baik jika pendampingan difokuskan pada satu atau dua benih usaha pariwisata saja sehingga perkembangannya dapat lebih optimum.

Berdasarkan survei/kunjungan/visitasi ke BUMDes Kertajaya dan lokasi wisata di Desa Kertajaya, maka potensi yang perlu digali terlebih dahulu melalui pendampingan dari Tim Pengabdian pada Masyarakat adalah Bumi Perkemahan. Dengan mengembangkan Bumi Perkemahan, maka solusi akan akomodasi yang lebih optimum akan dapat terpenuhi di tengah keterbatasan dana dan sumber daya yang ada namun dengan kekayaan alam (hutan lindung) yang sangat memadai. Harapannya adalah pengembangan Bumi Perkemahan ini akan membuka peluang lebih banyak bagi 6 benih usaha pariwisata di Desa Kertajaya, mengingat jarak antara Bumi Perkemahan dengan 6 benih usaha pariwisata lainnya di Desa Kertajaya cukup dekat (masih dalam lingkup $1 \mathrm{RW}$ ).

\section{KESIMPULAN}

\subsection{Kesimpulan}

Berdasarkan analisis dan pembahasan yang telah disajikan, maka kesimpulan yang dapat diambil dari penelitian kami mengenai potensi desa wisata di Kertajaya adalah:

1. Desa Kertajaya cukup berpotensi menjadi Desa Wisata melalui kerjasama BUMDes dan penduduk Desa Kertajaya. Hal ini terlihat dari indeks potensi desa wisata yakni sebesar 2,79 yang merupakan hasil analisis potensi Desa Wisata dari dimensi (A) sikap dan tata kehidupan masyarakat, (B) aksesibilitas, (C) amenity, (D) kelembagaan, promosi dan informasi, serta (E) budaya dan situs purbakalanya.

2. Terdapat beberapa kendala yang perlu diatas agar Desa Wisata di Desa Kertajaya dapat menarik para wisatawan dari luar daerah dan mampu bersaing dengan pusat wisata lain di Indonesia. Kendala tersebut meliputi: jalan menuju lokasi yang belum memadai, penerangan yang belum cukup menerangi jalan akses tersebut, sumber daya yang terbatas, transportasi umum yang masih minim, dan terutama adalah akomodasi yang belum memadai.

3. Terdapat potensi yang cukup baik untuk mengembangkan akomodasi dengan dana dan sumber daya terbatas, yakni pengembangan Bumi Perkemahan di Desa Kertajaya, sehingga wisatawan dapat memperoleh akomodasi yang nyaman namun mengesankan dengan biaya yang tidak sebesar ketika mengembangkan guesthouse di daerah tersebut. Dalam hal ini, Desa Kertajaya memiliki potensi berupa lahan hutan lindung yang cukup luas dan memberikan kesan alam yang menarik bagi wisatawan serta lokasi Bumi Perkemahan yang tidak jauh dari pusat wisata lainnya di Desa Kertajaya. 


\subsection{Saran}

Berdasarkan beberapa kesimpulan yang telah disajikan pada bagian 5.1 di atas, maka saran dari kegiatan ini adalah:

1. Sebaiknya pembangunan infrastruktur berupa jalan yang lebar, baik dan terang dapat dilakukan secara berkesinambungan

2. Sebaiknya pengembangan transportasi selain ojek perlu dilakukan sehingga dapat mengakomodir kebutuhan wisatawan yang berkunjung dengan keluarga atau temantemannya.

3. Sebaiknya diadakan pendampingan dalam hal peningkatan kompetensi orang-orang yang terlibat di bidang usaha pariwisata ini sehingga pengelolaan Desa Wisata dapat lebih optimum dan mampu mengejar perkembangan terkini dari selera para wisatawan.

4. Perlu diadakan pendampingan dalam mengembangkan satu benih wisata di Desa Kertajaya yaitu Bumi Perkemahan sehingga masalah akomodasi dapat teratasi dalam waktu lebih singkat dengan sumber daya yang ada.

\section{DAFTAR PUSTAKA}

Adam, H., Ristawati, R., Ramadhanti, S., \& Nugraha, X. (2020). Pembentukan Badan Usaha Milik Desa Di Sumberanyar Pasuruan Untuk Peningkatan Kesejahteraan Masyarakat. Dinamisia: Jurnal Pengabdian Kepada Masyarakat, 4(2), 293-299. https://doi.org/10.31849/DINAMISIA.V4I2.3414

Andriani, R. A., Wibowo, A. A., \& Winarno, J. A. (2020). Analisis Kebutuhan Masyarakat dalam Pengembangan Dewi Sambi (Desa Wisata Samiran Boyolali) di Desa Samiran, Kecamatan Selo, Kabupaten Boyolali. Jurnal Nasional Pariwisata, 12(2), 82-88. https://doi.org/10.22146/JNP.60399

Crnogaj, K., Rebernik, M., Hojnik, B. B., \& Gomezelj, D. O. (2014). Building a model of researching the sustainable entrepreneurship in the tourism sector. Kybernetes, 43(3), 377-393. https://doi.org/10.1108/K-07-2013-0155

Gunn, C. A., \& Var, T. (2002). Tourism planning : basics, concepts, cases. 442.

Hanny, H., Agustina, L., Lingga, I. S., Rapina, R., Carolina, Y., Marpaung, E. I., Erna, E., Kambono, H., Tjun, L. T., Oktavianti, O., \& Goiyardi, E. (2020). Analisis Pemetaan Profil Badan Usaha Milik Desa Serta Potensi dan Permasalahannya di Bidang Pengelolaan Air Bersih: (studi kasus di BUMDes Kertajaya, Cianjur, Provinsi Jawa Barat). Patria: Jurnal Pengabdian Kepada Masyarakat, 2(1), 8-24. https://doi.org/10.24167/PATRIA.V2I1.2570

Jati, D. P., Suroso, A., \& Suwandari, L. (2014). Analisis Kelayakan Desa Kalisari sebagai Desa Wisata:Aspek Sosial Ekonomi, Operasional dan Pemasaran. The 3rd Economics \& Business Research Festival, 454-464.

Kurniawan, A. (2021). Bumdes Kertajaya, Akan Fokus Mengelola Destinasi Wisata / Metro Puncak News. Https://Metropuncaknews.Com/. https://metropuncaknews.com/bumdes-kertajayaakan-fokus-mengelola-destinasi-wisata/

Lembaga Penyelidikan Ekonomi dan Masyarakat Fakultas Ekonomi dan Bisnis Universitas Indonesia. (2018). Laporan Akhir Kajian Dampak Sektor Pariwisata terhadap Perekonomian Indonesia.

https://www.kemenparekraf.go.id/asset_admin/assets/uploads/media/pdf/media_155443 7393_Laporan_Akhir.pdf

Peraturan Pemerintah Republik Indonesia Nomor 11 Tahun 2021 Tentang Badan Usaha Milik Desa, (2021). https://jdih.setkab.go.id/PUUdoc/176380/PP_Nomor_11_Tahun_2021.pdf

Sjamsu, A. S., \& Dahrma, I. M. K. A. (2018). Studi Kelayakan Potensi Pengembangan Desa Wisata Di Kawasan Pulau Saponda Dalam Kabupaten Konawe. Seminar Nasional Teknologi Terapan Berbasis Kearifan Lokal, 1(1). http://ojs.uho.ac.id/index.php/snt2bkl/article/view/5241

Spillane, J. J. (1997). Pariwisata Indonesia Siasat Ekonomi dan Rekayasa Budaya. Kanisius dan Lembaga Studi Realino. 
Sutawa, G. K. (2012). Issues on Bali Tourism Development and Community Empowerment to Support Sustainable Tourism Development. Procedia Economics and Finance, 4, 413-422. https://doi.org/10.1016/S2212-5671(12)00356-5

Tyas, N. W., \& Damayanti, M. (2018). Potensi Pengembangan Desa Kliwonan sebagai Desa Wisata Batik di Kabupaten Sragen. Journal of Regional and Rural Development Planning (Jurnal Perencanaan Pembangunan Wilayah Dan Perdesaan), 2(1), 74-89. https://doi.org/10.29244/JP2WD.2018.2.1.74-89

Zakaria, F., \& Suprihardjo, R. (2014). Konsep Pengembangan Kawasan Desa Wisata di Desa Bandungan Kecamatan Pakong Kabupaten Pamekasan. Jurnal Teknik ITS, 3(2), C245-C249. https://doi.org/10.12962/j23373539.v3i2.7292

Zakaria, H. G. (2017). 5 Pilar Revolusi Mental Untuk Aparatur Negara. PT Elex Media Komputindo. 